\title{
Traditionally Used Plants in the Treatment of Diabetes Mellitus: Screening for Uptake Inhibition of Glucose and Fructose in the Caco2-Cell Model
}

OPEN ACCESS

Edited by:

Michał Tomczyk,

Medical University of Bialystok, Poland

Reviewed by:

Alexander N. Shikov, Saint-Petersburg State Chemical Pharmaceutical Academy, Russia Judith Maria Rollinger, University of Vienna, Austria

*Correspondence:

Matthias F. Melzig melzig@zedat.fu-berlin.de

Specialty section: This article was submitted to

Ethnopharmacology,

a section of the journal

Frontiers in Pharmacology

Received: 08 April 2021 Accepted: 15 July 2021 Published: 20 August 2021

Citation:

Schreck K and Melzig MF (2021) Traditionally Used Plants in the

Treatment of Diabetes Mellitus: Screening for Uptake Inhibition of Glucose and Fructose in the Caco2-

Cell Model.

Front. Pharmacol. 12:692566. doi: 10.3389/fphar.2021.692566

\author{
Katharina Schreck and Matthias F. Melzig * \\ Pharmaceutical Biology, Institute of Pharmacy, Freie Universitaet Berlin, Berlin, Germany
}

The traditional use of plants and their preparations in the treatment of diseases as a first medication in the past centuries indicates the presence of active components for specific targets in the natural material. Many of the tested plants in this study have been traditionally used in the treatment of Diabetes mellitus type 2 and associated symptoms in different cultural areas. Additionally, hypoglycemic effects, such as a decrease in blood glucose concentration, have been demonstrated in vivo for these plants. In order to determine the mode of action, the plants were prepared as methanolic and aqueous extracts and tested for their effects on intestinal glucose and fructose absorption in Caco2 cells. The results of this screening showed significant and reproducible inhibition of glucose uptake between 40 and $80 \%$ by methanolic extracts made from the fruits of Aronia melanocarpa, Cornus officinalis, Crataegus pinnatifida, Lycium chinense, and Vaccinium myrtillus; the leaves of Brassica oleracea, Juglans regia, and Peumus boldus; and the roots of Adenophora triphylla. Furthermore, glucose uptake was inhibited between 50 and $70 \%$ by aqueous extracts made from the bark of Eucommia ulmoides and the fruit skin of Malus domestica. The methanolic extracts of Juglans regia and Peumus boldus inhibited the fructose transport between 30 and $40 \%$ in Caco2 cells as well. These findings can be considered as fundamental work for further research regarding the treatment of obesity-correlated diseases, such as Diabetes mellitus type 2.

Keywords: plant extracts, traditional use, glucose, fructose, uptake inhibition, Diabetes mellitus, Caco2 cells

\section{INTRODUCTION}

In the last years, not only did the absolute number of people suffering from Diabetes mellitus increase from 108 Mio in 1980 to 422 Mio in 2014 but also the prevalence of this disease rose from 4.7 to $8.5 \%$ among adults during this time period worldwide (WHO, 2019). Apart from the estimated annual cost to the world of US\$ 827 billion, Diabetes is associated with premature mortality and decreased quality of life (WHO, 2016). Hyperglycemia, as one of the main symptoms for diagnosis, results from decreased insulin secretion and/or reduced insulin action and can lead to long-term damage and dysfunction of different organs (American Diabetes Associa, 2014). Particularly, the most common kind of the disease, Diabetes mellitus type 2 (American Diabetes Associa, 2014), can be prevented or delayed in its progress by a lifestyle, which includes a healthy diet, regular exercise with moderate intensity, and no tobacco use (WHO, 2019). 
With a focus on the diet, not only a decrease of energy intake to reduce obesity (Grundy, 1998) but also the selection of the consumed food can improve the health status. Supplements can be used to ensure the adequate intake of certain nutrients and support patient's therapy (Ota and Ulrih, 2017). For example, the reduction of glucose, fructose, and saturated long-chain fatty acids and the increased intake of polyunsaturated, omega- 3 fatty acids, such as eicosapentaenoic and docosahexaenoic acid, play a very important role in the prevention and improvement of metabolic disorders by alleviating inflammation processes (Sears and Perry, 2015). Regarding the consumption of plant-based food, secondary metabolites from plants showed hypoglycemic properties by affecting different targets, for example, modulation of intracellular insulin signaling pathways, increase in insulin secretion from $\beta$-cells, and inhibition of intestinal enzymes and transporters (Hanhineva et al., 2010; Bahadoran et al., 2013; Ota and Ulrih, 2017). In order to treat obesity as one of the main risk factors for Diabetes mellitus type 2 (Smith, 2007), the reduction of nutritional uptake into enterocytes as the last step before energy overload affects the body is an important therapeutic approach. Furthermore, the inhibition of enzymes and transporters leads to increased concentrations of nutrients in distal sections of the small intestine, which initiates the "ileal brake." This complex mechanism is known to influence the digestive process and ingestive behavior resulting in reduced appetite and food intake (Maljaars et al., 2008). The glucose transport in the small intestine is maintained by the cotransporter SGLT1 (sodium-glucose linked transporter 1) and GLUT2 (glucose transporter 2), which belongs to the GLUT family and facilitates diffusion processes. The intestinal fructose uptake is performed by GLUT5 (glucose transporter 5) and GLUT2 as well (Schreck and Melzig, 2018). Medicinal plants traditionally used in the treatment of diseases have been applied as candidates for drug discovery in the last decades (Fabricant and Farnsworth, 2001). Aspirin, atropine, ephedrine, digoxin, and morphine are examples of effective substances, which owe their discovery to investigative studies of folk medicine (Gilani and Atta-ur-RahmanTrends, 2005). Ethnopharmacology studies show the continuing acceptance of traditionally used plant preparations as a therapy option due to their long-term experience and marginal side effects (Fabricant and Farnsworth, 2001; Gilani and Atta-ur-RahmanTrends, 2005). The plants tested in this study were chosen due to their traditional use in some cultural areas and countries during the last centuries and their hypoglycemic effects, which were discovered in animal or human studies, as listed in Table 1. For example, in Jordan, preparations of Allium sativum, Ceratonia siliqua, Cuminum cyminum, Juglans regia, Nigella sativa, Olea europaea, Sarcopoterium spinosum have been used in the treatment of Diabetes mellitus (Al-Aboudi and Afifi, 2011), whereas in Congo, Brassica oleracea and Citrus limon have been prepared as folk medicine to treat Diabetes mellitus (Katemo et al., 2012). The plants Adenophora triphylla, Cornus officinalis, Crataegus pinnatifida, Eucommia ulmoides, Lycium chinense, Pueraria lobata, and Rosa rugosa belong to the pharmacopoeia of the Traditional Chinese Medicine (Stöger, 2009). Although Adenophora triphylla and Crataegus pinnatifida showed hypoglycemic effects in studies, the traditional use as antidiabetic remedy was not confirmed in English-language literature as shown in Table 1. According to Table 1, some of the plants, such as Olea europaea and Brassica oleracea, were used in different areas of the world supporting the assumption of efficacy in the treatment of the metabolic disorder. The plants used in this study have been already tested in animal experiments and hypoglycemic properties such as a decrease in blood glucose were confirmed as shown in Table 1, but the exact mechanisms still need to be studied. In order to determine the mode of action, methanolic and aqueous plant extracts were screened for their inhibitory activity on intestinal transporters using Caco2 cells, which originally stem from a colorectal adenocarcinoma cell line. After confluence, the cells need 15-21 days to differentiate and fully express intestinal characteristics, such as a brush border membrane with enzymes and transporters. The adenocarcinoma cell line is widely used as a model for intestinal transport studies (Chantret et al., 1988; Hidalgo et al., 1989; Jumarie and Malo, 1991; Sambuy et al., 2005). We have determined the expression of the SGLT1, GLUT2, and GLUT5 transporters in the Caco2 cells during 21 days (Schreck and Melzig, 2019) and adapted the experimental conditions to ensure valuable results.

\section{MATERIALS AND METHODS}

\section{Plant Extract Preparations}

The methanolic and aqueous extract preparations were performed according to Buchholz (2017) with modifications. The parts of the plants, which were used to prepare the extracts, are listed in Tables 2, 3. Except for the fresh fruits of Malus domestica, the botanicals were obtained as dried plant material from the companies. The bulbs of Allium sativum, fruits of Aronia melanocarpa and Vaccinium myrtillus, fruit skin of Punica granatum, the herbal part of Cynara cardunculus and Potentilla aurea, leaves of Mentha aquatica and Olea europaea, roots of Panax ginseng and Sarcopoterium spinosum, and seeds of Nigella sativa were purchased from Kräuter Schulte aktiv Kräuter Drogerie e.K. (Gernsbach, Germany). The following herbal drugs were obtained from Alfred Galke GmbH (Gittelde, Germany): flowers of Hibiscus sabdariffa and Syzygium aromaticum; fruits of Ceratonia siliqua; fruit skin of Citrus limon; leaves of Brassica oleracea, Camellia sinensis, Ilex paraguariensis, Juglans regia, Melissa officinalis, Origanum creticum, Rosmarinus officinalis, and Salvia officinalis; and seeds of Cuminum cyminum and Vitis vinifera (pomace). The plant materials used in Traditional Chinese Medicine, such as the bark of Eucommia ulmoides; flowers of Rosa rugosa; fruits of Cornus officinalis, Crataegus pinnatifida, and Lycium chinense; and the roots of Adenophora triphylla and Pueraria lobata were acquired from Zieten Apotheke (Berlin, Germany). The fruits of the cucurbitaceae Momordica charantia were kindly given by Dr. Serhat Sezai Çiçek (Institute of Pharmacy of Christian-AlbrechtsUniversitaet Kiel, Germany). The green seeds of Coffea arabica were purchased from Ridders Kaffeerosterei (Berlin, Germany). The leaves of Peumus boldus were gained from Heinrich Klenk $\mathrm{GmbH} \& \mathrm{Co}$. KG (Schwebheim, Germany), whereas the leaves of Artemisia dracunculus and the fresh fruits of Malus domestica 
TABLE 1 | Selected plants, which are/were traditionally used in specific countries and their antidiabetic effects measured in studies and discussed active compounds (n.f. = not found in English-language literature for this indication; n.n. = not named).

\section{Scientific plant name \\ to conventional treatments \\ in the therapy \\ of Diabetes mellitus \\ (reference)}

\section{Selected, antidiabetic effects \\ of traditionally used \\ plants measured in \\ studies}

Discussed active compounds

Reference for

antidiabetic

effects and discussed

active compounds n.f.

(THUNB.) ADC.

Allium sativum L.

Jordan Al-Aboudi and Afifi (2011), Morocco Idm'hand et al. (2020), India Rizvi and Mishra (2013), United Kingdom Swanston-Flatt et al. (1991)

Aronia melanocarpa n.f.

MICHX. ELLIOTT

Artemisia

dracunculus L.

United Kingdom Swanston-Flatt et al. (1991)

Congo Katemo et al. (2012), Morocco Idm'hand et al. (2020), United Kingdom Swanston-Flatt et al. (1991)

Camellia sinensis (L.) KUNTZE (Assam)

Camellia sinensis (L.) KUNTZE (Darjeeling)

Camellia sinensis (L.) KUNTZE (gunpowder) Camellia sinensis (L) KUNTZE (Sencha)

Ceratonia siliqua L

Jordan Al-Aboudi and Afifi (2011), Morocco Idm'hand et al. (2020)

Citrus limon (L.)

OSBECK

Congo Katemo et al. (2012), United Kingdom Swanston-Flatt et al. (1991)

Coffea arabica n.f.

Cornus officinalis SIEBOLD and ZUCC.

Crataegus pinnatifida n.f. BUNGE

Cuminum cyminum L. Jordan Al-Aboudi and Afifi (2011), Morocco Idm'hand et al. (2020)

Cynara cardunculus L.

Morocco Idm'hand et al. (2020); Tahraoui et al. (2007)

Eucommia ulmoides OLIV.

Hibiscus sabdariffa L. Morocco ldm'hand et al. (2020)
Decrease of blood glucose, inhibition of intestinal glucose absorption in rats and mice

Decrease of serum glucose and triglycerides, increase of serum insulin levels in diabetic rats

Decrease of serum glucose and lipids, reduced $\alpha$-glucosidase activity

Decrease of elevated blood glucose level and blood insulin concentrations in diabetic mice

Decrease of blood glucose in diabetic rats, decrease of blood lipids, and restoration of renal function in rats

Decrease of blood glucose level in rats/mice, reduced $a$-glucosidase, $\alpha$-amylase, and lipase activity

Catechins, flavanols, polysaccharides

Flavonoids (luteolin, apigenin), coumarins (scopoletin), sesquiterpenoid lactones (costunolide), cinnamates n.n.

Kataya and Hamza (2008); Assad et al. (2014); Shah et al. (2016)

Gomes et al. (1995); Han et al. (2011); Wang et al. (2017)

Decrease of blood glucose in rats, reduced $\alpha$-glucosidase, $\alpha$-amylase activity, inhibition of intestinal glucose transport

Decrease of blood glucose in rats

Decrease of blood glucose in rats, reduced glucose uptake, stimulated insulin secretion

China Li et al. (2004); Ma et al. (2014) Decrease of blood glucose in mice, reduced $\alpha$-glucosidase activity, increased glucose uptake in HepG2 Decrease of hyperglycemia in rats, modulation of insulin regulation, antiobesity effect, anti-hyperlipidemia effect, reduced rats' a-glucosidase activity

Decrease of hyperglycemia, oxidative stress, and AGE formation in rats, reduced $\alpha$-glucosidase activity Decrease in blood glucose and serum lipid levels in humans and rats

Decrease in blood glucose and increase in plasma insulin in rats, decreased plasma lipid levels in mice, reduced glycation n.n.

Naim et al. (2012)

Polyphenolic compounds

Rtibi et al. (2017)

Caffeine, polyphenolic compounds: chlorogenic acid, quinolactones

Morroniside, loganin, ursolic acid (2013)

Flavonoids, hyperosid, chlorogenic acid, tripenic acids

Cuminaldehyde, flavonoids

Jagtap and Patil (2010)

Flavonoids

Nazni et al. (2006); (2011)

Flavonoids

Kim et al. (2004); Lee et al. (2005); Park et al. (2006)

Polyphenolic compounds Heidarian and Soofiniya
Peng et al. (2011)

(Continued on following page) 
TABLE 1 | (Continued) Selected plants, which are/were traditionally used in specific countries and their antidiabetic effects measured in studies and discussed active compounds (n.f. = not found in English-language literature for this indication; n.n. = not named).

\begin{tabular}{|c|c|c|c|c|}
\hline $\begin{array}{l}\text { Scientific plant } \\
\text { name }\end{array}$ & $\begin{array}{c}\text { Countries/areas with traditional } \\
\text { use of plant } \\
\text { preparations as antidiabetic } \\
\text { remedy and adjuncts } \\
\text { to conventional treatments } \\
\text { in the therapy } \\
\text { of Diabetes mellitus } \\
\text { (reference) }\end{array}$ & $\begin{array}{l}\text { Selected, antidiabetic effects } \\
\text { of traditionally used } \\
\text { plants measured in } \\
\text { studies }\end{array}$ & Discussed active compounds & $\begin{array}{c}\text { Reference for } \\
\text { antidiabetic } \\
\text { effects and discussed } \\
\text { active compounds }\end{array}$ \\
\hline
\end{tabular}

Decreased hyperglycemia, hyperinsulinemia, serum lipids, and

Ilex paraguariensis A. South America de Freitas Junior and ST.-HIL de Almeida (2017)

Juglans regia L. Jordan Al-Aboudi and Afifi (2011), Morocco Idm'hand et al. (2020)

Lycium chinense MILL. China Li et al. (2004)

Malus domestica Morocco Idm'hand et al. (2020) BORKH.

Melissa officinalis L. Iran, Turkey Shakeri et al. (2016)

Mentha aquatica L. n.f.

Momordica

charantia L.

Nigella sativa L.

Olea europaea L. Jordan Al-Aboudi and Afifi (2011), Morocco Idm'hand et al. (2020), Portugal Neves et al. (2009)

Origanum creticum L. Morocco Idm'hand et al. (2020)

Panax ginseng Asia Park et al. (2019)

C.A. MEY.

Peumus boldus n.f.

MOLINA

Potentilla aurea L. n.f.

Pueraria lobata China Li et al. (2004)

(WILLD.) OHWI

Punica granatum L. Morocco ldm'hand et al. (2020); (peel)

Decrease of plasma glucose level,
AGE formations in rats

Decrease of serum lipids and glucose in mice, modulation of food intake Decrease of fasting blood glucose, $\mathrm{HbA} 1 \mathrm{c}$, and fasting blood lipids in humans

Decrease of blood glucose and attenuation of dyslipidemia in rats Decrease of postprandial blood glucose in mice and humans, decrease of glucose absorption in mouse intestine, inhibition of human SGLT1 in $X$. laevis oocytes, inhibition of lipase in vitro, and decrease of plasma triglycerides in mice and humans

Decrease of plasma glucose levels in rats, reduced a-glucosidase, $\alpha$-amylase activity, decrease of $\mathrm{HbA} 1 \mathrm{c}$, serum triglyceride and fasting blood glucose levels in humans Decrease of fasting blood glucose and lipid levels, nephroprotective, reduced $\mathrm{HbA} 1 \mathrm{c}$, and increase of insulin levels in rats

Decrease of blood glucose and glycosylated haemoglobin and increase of plasma insulin in animal studies, inhibition of intestinal transporters

Decrease of fasting blood glucose, reduced insulin resistance, and improved $\beta$-cell function

Decrease of serum blood glucose, triglycerides, and cholesterol, increase of serum insulin levels

Decrease of blood glucose, lipids, and n.n. $\mathrm{HbA1c}$ in rats, reduced $\mathrm{a}$-amylase activity

Decrease of 75 g-OGTT-plasmaglucose indices, fasting plasma insulin, and 75 g-OGTT-plasma-insulin indices in humans inhibition of $a$-amylase and lipase

Inhibition of $\alpha$-amylase and lipase

Decrease of fasting blood glucose, improved glucose tolerance and insulin sensitivity in mice Decrease of fasting blood glucose and Phenolic compounds serum lipids in rats

3-arabinoside volatile oils ic, oleanolic acid 3-O3-O-glucuronide

n.n.

Oleuropeoside

Boldine
Polyphenolic compounds,

methylxanthines, saponins

Phenolic acids and flavonoids: 3- Hosseini et al. (2014)

and 5-caffeoylquinic acids,

quercetin-3-galactoside, quercetin-

Polyphenolic compounds

Olatunji et al. (2017)

Polyphenolic compounds: quercetin, phlorizin, procyanidins

Sugiyama et al. (2007); Schulze et al. (2014)

Polyphenolic compounds

Hasanein and Riahi (flavonoids), essential oils

(2015); Asadi et al. (2019)

Polyphenolic compounds

(flavonoids, tannins), saponins,

Charantin, polypeptide-p, momordin

monodesmoside, and oleanolic acid

Bamosa et al. (2010)

Eidi et al. (2009)

Prasanna et al. (2017)

Ginsenosides: PPT, (20R)-PPD,

Vuksan et al. (2008)

Rg1, Rc, Rd, Re, Rf, Rg2, Rh1, Rb1, and $\mathrm{Rb} 2$; peptidoglycan: panaxan $\mathrm{B}$

Jang et al. (2000);

Buchholz and Melzig

(2016)

Buchholz and Melzig

(2016)

Prasain et al. (2012)

Bagri et al. (2009)

(Continued on following page) 
TABLE 1 | (Continued) Selected plants, which are/were traditionally used in specific countries and their antidiabetic effects measured in studies and discussed active compounds (n.f. = not found in English-language literature for this indication; n.n. = not named).

\begin{tabular}{|c|c|c|c|c|}
\hline $\begin{array}{l}\text { Scientific plant } \\
\text { name }\end{array}$ & $\begin{array}{c}\text { Countries/areas with traditional } \\
\text { use of plant } \\
\text { preparations as antidiabetic } \\
\text { remedy and adjuncts } \\
\text { to conventional treatments } \\
\text { in the therapy } \\
\text { of Diabetes mellitus } \\
\text { (reference) }\end{array}$ & $\begin{array}{l}\text { Selected, antidiabetic effects } \\
\text { of traditionally used } \\
\text { plants measured in } \\
\text { studies }\end{array}$ & Discussed active compounds & $\begin{array}{c}\text { Reference for } \\
\text { antidiabetic } \\
\text { effects and discussed } \\
\text { active compounds }\end{array}$ \\
\hline Rosa rugosa THunB. & Korea Lee et al. (2008) & $\begin{array}{l}\text { Decrease of blood glucose, serum } \\
\text { insulin, serum lipids, increased insulin } \\
\text { sensitivity in rats, reduced } \\
\text { a-glucosidase activity }\end{array}$ & Polyphenolic compounds & Liu et al. (2017) \\
\hline $\begin{array}{l}\text { Rosmarinus } \\
\text { officinalis L. }\end{array}$ & $\begin{array}{l}\text { Morocco Idm'hand et al. (2020); } \\
\text { Tahraoui et al. (2007) }\end{array}$ & $\begin{array}{l}\text { Decrease of blood glucose and } \\
\text { increase of serum insulin in rabbits, } \\
\text { reduced } \alpha \text {-glucosidase activity }\end{array}$ & Volatile oils & Bakırel et al. (2008) \\
\hline Salvia officinalis L. & $\begin{array}{l}\text { Morocco Idm'hand et al. (2020); } \\
\text { Tahraoui et al. (2007), } \\
\text { United Kingdom Swanston-Flatt et al. } \\
\text { (1991) }\end{array}$ & $\begin{array}{l}\text { Decrease in 2-h-postprandial blood } \\
\text { glucose and cholesterol in humans, } \\
\text { decrease in serum glucose and lipids } \\
\text { in rats }\end{array}$ & $\begin{array}{l}\text { Flavonoids (rosmarinic acid, phenolic } \\
\text { acids, carnosic compounds) }\end{array}$ & $\begin{array}{l}\text { Eidi and Eidi (2009); } \\
\text { Behradmanesh et al. } \\
(2013)\end{array}$ \\
\hline $\begin{array}{l}\text { Sarcopoterium } \\
\text { spinosum (L.) SPACH }\end{array}$ & $\begin{array}{l}\text { Jordan Al-Aboudi and Afifi (2011), } \\
\text { Israel Bachrach (2007) }\end{array}$ & $\begin{array}{l}\text { Improved glucose tolerance in mice, } \\
\text { insulin-like effects, increased insulin } \\
\text { secretion in vitro, reduced } \\
\text { a-glucosidase and a-amylase activity }\end{array}$ & $\begin{array}{l}\text { Polyphenolic compounds: catechin, } \\
\text { epicatechin }\end{array}$ & $\begin{array}{l}\text { Smirin et al. (2010); } \\
\text { Elyasiyan et al. (2017) }\end{array}$ \\
\hline $\begin{array}{l}\text { Syzygium } \\
\text { aromaticum (L.) MERR. } \\
\text { and L.M.PERRY }\end{array}$ & Morocco Idm'hand et al. (2020) & $\begin{array}{l}\text { Decrease of postprandial } \\
\text { hyperglycemia in rats, reduced } \\
\text { a-glucosidase and a-amylase activity, } \\
\text { downregulation of intestinal } \\
\text { transporters }\end{array}$ & $\begin{array}{l}\text { Triterpenes (oleanolic acid, maslinic } \\
\text { acid) }\end{array}$ & Khathi et al. (2013) \\
\hline Thymus vulgaris $\mathrm{L}$. & $\begin{array}{l}\text { Morocco Idm'hand et al. (2020), } \\
\text { United Kingdom Swanston-Flatt et al. } \\
\text { (1991) }\end{array}$ & $\begin{array}{l}\text { Reduced blood glucose and serum } \\
\text { lipids in rats }\end{array}$ & Flavonoids & Ekoh et al. (2014) \\
\hline Vaccinium myrtillus L. & Europe Helmstaedter (2007) & $\begin{array}{l}\text { Decrease of blood glucose and lipids } \\
\text { in rats }\end{array}$ & Polyphenolic compounds & Sidorova et al. (2017) \\
\hline Vitis vinifera $\mathrm{L}$. & Morocco Idm'hand et al. (2020) & $\begin{array}{l}\text { Decrease of postprandial } \\
\text { hyperglycemia in mice, reduced } \\
\text { a-glucosidase activity }\end{array}$ & $\begin{array}{l}\text { Polyphenolic compounds: } \\
\text { flavonoids, anthocyanins }\end{array}$ & Hogan et al. (2010) \\
\hline
\end{tabular}

were obtained from a local supermarket. The fresh fruits of Malus domestica were washed with water. The fruit's skin was cut into small pieces, dried in a drying cabinet at $40^{\circ} \mathrm{C}$ for 3 days, and freeze-dried for $48 \mathrm{~h}$. The dried plant material was ground with a M20 mill from IKA ${ }^{\circledR}$-Werke $\mathrm{GmbH}$ \& Co. KG (Staufen, Germany). $10.0 \mathrm{~g}$ of the plant's powder, adjusted to the drug extract ratio as listed in Tables 2, 3, was extracted in $100 \mathrm{ml}$. For the preparation of the aqueous extracts, plant material was extracted in water obtained from the ultrapure water system LaboStar from Siemens AG Wasseraufbereitung (Barsbüttel, Germany) for $15 \mathrm{~min}$ at $40^{\circ} \mathrm{C}$ and filtered with a Buechner filter. In some cases, extracts were centrifuged at $4^{\circ} \mathrm{C}$ first with an Allegra X-30R centrifuge from Beckman Coulter $\mathrm{GmbH}$ (Krefeld, Germany) to facilitate the filtration process. The extracts were freeze-dried for at least $48 \mathrm{~h}$ with the lyophilization machine Alpha 2-4 LSCplus from Martin Christ Gefriertrocknungsanlagen $\mathrm{GmbH}$ (Osterode am Harz, Germany). The powder was stored at $-20^{\circ} \mathrm{C}$ until use. For the preparation of the methanolic extracts, plant material was extracted in methanol purchased from VWR International S.A.S. (Fontenay-sous-Bois, France) for $60 \mathrm{~min}$ at $40^{\circ} \mathrm{C}$ and filtered. In order to obtain a dry powder, they were evaporated to $5 \mathrm{ml}$ with the rotary evaporator RV 10 basic from IKA ${ }^{\circledR}$-Werke $\mathrm{GmbH} \&$ Co. KG (Staufen, Germany) and dried in a Petri dish from VWR International GmbH (Darmstadt, Germany) under the exhaust hood overnight. Subsequently, the extracts were freeze-dried to lose residual water and stored at $-20^{\circ} \mathrm{C}$ until use. For application in cell experiments, the aqueous extracts were solved in DPBS (Dulbecco's phosphate-buffered saline) purchased from Lonza Cologne AG (Cologne, Germany), whereas the extracts made with methanol were first dissolved in DMSO $(0.3 \% \mathrm{~V} / \mathrm{V}$ final well concentration), which was acquired from Fisher Scientific GmbH (Schwerte, Germany), and filled with DPBS until final volume. Extract solutions were filtered with a $0.8 \mu \mathrm{m}$ and a $0.2 \mu \mathrm{m}$ sterile filter purchased from Carl Roth GmbH + Co. KG (Karlsruhe, Germany) and stored at $-20^{\circ} \mathrm{C}$ until use. Three different extract concentrations (1.0, 0.1, or $0.01 \mathrm{mg} / \mathrm{ml})$ were tested in MTT assay [3- $(4,5-$ dimethylthiazol-2-yl)-2,5-diphenyltetrazolium bromide] as described in the Supplementary Material and only the highest concentration, which did not affect cell viability, was used in uptake studies. The GLUT2 inhibitor phloretin, which was purchased from Cayman Chemical (Michigan, United States), and the SGLT1 inhibitor phlorizin applied from Carl Roth $\mathrm{GmbH}$ 
+ Co. KG (Karlsruhe, Germany) were used with a final well concentration of $100 \mu \mathrm{M}$ as a positive control for uptake inhibition of glucose.

\section{General Handling of the Cell Line}

Caco2 cells were purchased from Leibniz-Institut DSMZDeutsche Sammlung von Mikroorganismen und Zellkulturen $\mathrm{GmbH}$ (Braunschweig, Germany) and seeded in 24-well plates, which were acquired from Greiner Bio-One $\mathrm{GmbH}$ (Frickenhausen, Germany), for every experiment. As general medium DMEM (Dulbecco's modified eagle medium) without phenol red containing $1 \%$ UltraGlutamine 1, both acquired from Lonza Cologne AG (Cologne, Germany) and 5 or 20\% FBS derived from Bio\&SELL GmbH (Nürnberg, Germany) for experiment or mother line, respectively, was used for the handling with $\mathrm{Caco} 2$ cells. Cells were washed once with PBS from Lonza Cologne AG (Cologne, Germany) for every medium change and washed twice before Trypsin (TrypLE ${ }^{\mathrm{TM}}$ Express without phenol red) from Gibco Life Technologies corporation (NY, United States) was applied to detach the cells for seeding. The cells were incubated at $37^{\circ} \mathrm{C}$ and $5 \% \mathrm{CO}_{2}$-supply during the whole time. Passages $20-35$ were used in the experiments. The buffers and solutions for cell culture were prepared with water obtained from the ultrapure water system LaboStar from Siemens AG Wasseraufbereitung (Barsbüttel, Germany).

\section{Glucose and Fructose Uptake in Caco2 Cells}

For uptake studies, cells were seeded in a density of 400,000 cells per well. Confluence appeared $24 \mathrm{~h}$ after seeding and was controlled visually. The radiolabeled substrates $1 \mathrm{mCi} / \mathrm{ml}$ glucose (specific activity: $30 \mathrm{Ci} / \mathrm{mmol}$ ) and $1 \mathrm{mCi} / \mathrm{ml}$ fructose (specific activity: $5 \mathrm{Ci} / \mathrm{mmol}$ ) were obtained from Biotrend Chemikalien $\mathrm{GmbH}$ (Köln, Germany). Although fructose absorption into cells was determined by using $54 \mathrm{nM}$ solution of radiolabeled substrate as final well concentration, the $2 \mathrm{nM}$ radiolabeled glucose solution was spiked with $0.001 \mu \mathrm{M}$ nonradiolabeled glucose, which was purchased from Merck KGaA (Darmstadt, Germany). For uptake studies with extracts, cells were used at day three and day fifteen after confluence for glucose and fructose, respectively. On the day of the experiment, cells were washed once with $2 \mathrm{ml}$ buffer containing $20 \mathrm{mM}$ Hepes [4(2-hydroxyethyl)-1-piperazineethanesulfonic acid], which was obtained from Carl Roth $\mathrm{GmbH}+$ Co. KG (Karlsruhe, Germany) and $150 \mathrm{mM} \mathrm{NaCl}$ purchased from Fisher Scientific $\mathrm{GmbH}$ (Schwerte, Germany). The $\mathrm{pH}$ of the buffer was adjusted with sodium hydroxide from Merck KGaA (Darmstadt, Germany) using a 766 Laboratory $\mathrm{pH}$ meter from Knick Elektronische Messgeraete $\mathrm{GmbH} \&$ Co. KG (Berlin, Germany) to 7.4. After $1 \mathrm{~h}$ starving incubation with Hepes$\mathrm{NaCl}$ buffer at $37^{\circ} \mathrm{C}$, substrate or substrate-extract solution were added to the cells and incubated at $37^{\circ} \mathrm{C}$. After $1 \mathrm{~h}$, the buffer was discarded, the cells were washed once with $1 \mathrm{ml}$ icecold Hepes- $\mathrm{NaCl}$ buffer, and $500 \mu \mathrm{L}$ Hepes- $\mathrm{NaCl}$ solution containing $1 \%$ Triton $\mathrm{X} 100$ was added to each well. The samples were taken from the well plates, added to a sufficient volume of scintillation cocktail in scintillation tubes, both purchased from Hidex (Mainz, Germany), mixed for $20 \mathrm{~s}$ using a vortexer from Heidolph Instruments $\mathrm{GmbH} \& \mathrm{Co}$. KG (Schwabach, Germany), and measured with a $\beta$-Counter from Hidex (Mainz, Germany). The plant extracts, which showed the strongest inhibition on intestinal glucose transporters, were repeated and tested for their influence on fructose uptake with a focus on methanolic extracts. Randomly, well plates, which were cultivated and treated under the same conditions as cells used for uptake studies, were tested in Hoechst Assay as described in the Supplementary Material to determine variations depending on the procedure.

\section{Statistical Evaluation and Use of Software}

All statistical tests were performed using Microsoft Excel. Normal distribution was established via Shapiro-Wilk test manually before using Excel's tool "Data analysis" for provision of the $F$-test and the $t$-tests. If the data was not normally distributed, Mann-Whitney $U$ test was applied for further statistical analysis. $\mathrm{IC}_{50}$ data was calculated with GraphPad Prism 5.0.

\section{RESULTS}

\section{Uptake Studies with Glucose and Fructose}

In order to prevent decreased metabolic activity due to the use of toxic extracts, methanolic and aqueous plant preparations were tested in MTT assay and the concentration, which did not reduce cell viability significantly, was used for uptake studies as shown in Tables 2, 3. According to the results obtained from Hoechst Assay that showed an average coefficient of variation of $21.7 \%$ within 14 randomly tested well plates, uptake inhibition of plant extracts was distinguishable from general fluctuations in the procedure for values $>25 \%$. In every experiment, a control without extract was running and served as $100 \%$ uptake control. After correction of values by subtracting the blank, uptake inhibition was calculated as the difference between control and sample. The obtained values of monosaccharide uptake inhibition in $\mathrm{Caco} 2$ cells treated with methanolic and aqueous extracts are reported in Tables 2, 3, respectively. Only the herbal drugs that showed the strongest inhibition rates on glucose uptake were tested for fructose uptake inhibition. For some of the plants, methanolic and aqueous extracts decreased glucose uptake significantly. However, only the extract of a plant that showed stronger inhibition on glucose absorption was repeated and tested for its impact on fructose uptake as described for the following plants. Additionally, the focus for further studies was on methanolic extracts as they naturally contain fewer monosaccharides, which could interfere with the measurement. The methanolic extracts made from the fruits of Aronia melanocarpa (uptake inhibition: $57.1 \%$ ), Cornus officinalis (uptake inhibition: 73.8\%), Crataegus pinnatifida (uptake inhibition: 73.7\%), Lycium chinense (uptake inhibition: $75.2 \%$ ), and Vaccinium myrtillus (uptake inhibition: 79.9\%); the leaves of Brassica oleracea (uptake inhibition: $82.8 \%$ ), Juglans regia (uptake inhibition: 52.4\%), and Peumus boldus (uptake inhibition: $47.5 \%$ ); and the roots of Adenophora triphylla (uptake 
TABLE 2|Results of glucose and fructose uptake studies with methanolic extracts, the used plant part, drug extract ratio, and tested concentration, which did not show any influence on cells in MTT assay. Only the plants that showed the strongest inhibition rates on glucose uptake were tested for fructose uptake inhibition. Regarding methanolic and aqueous extracts, the extract of a plant that showed the stronger inhibition on glucose absorption was repeated and tested for its impact on fructose uptake; mean value $\pm \mathrm{SD}$; *significant difference in $U$-test $(n=2$ with 12 replicates each; two-sided; $\alpha=0.05)$; n.d. $=$ not determined.

\begin{tabular}{|c|c|c|c|c|c|}
\hline $\begin{array}{l}\text { Scientific plant } \\
\text { name }\end{array}$ & $\begin{array}{l}\text { Used part } \\
\text { of the } \\
\text { plant }\end{array}$ & $\begin{array}{c}\text { Drug extract } \\
\text { ratio for } \\
\text { methanolic extracts }\end{array}$ & $\begin{array}{c}\text { Used methanolic } \\
\text { extract concentration } \\
\text { in } \mathrm{mg} / \mathrm{mL}\end{array}$ & $\begin{array}{c}\text { Uptake inhibition } \\
\text { of glucose } \\
\text { in } \%\end{array}$ & $\begin{array}{l}\text { Uptake inhibition } \\
\text { of fructose } \\
\text { in } \%\end{array}$ \\
\hline Adenophora triphylla (THUNB.) ADC. & Root & n.d. & 1 & $64.6^{\star} \pm 4.5$ & $<25$ \\
\hline Allium sativum $\mathrm{L}$. & Bulb & $20: 1$ & 0.01 & $<25$ & n.d. \\
\hline Aronia melanocarpa MICHX. ELLIOTT & Fruit & n.d. & 1 & $57.1^{\star} \pm 7.2$ & $<25$ \\
\hline Artemisia dracunculus L. & Leaf & $9: 1$ & 0.1 & $<25$ & n.d. \\
\hline Brassica oleracea L. "Capitata alba” & Leaf & $3: 1$ & 1 & $82.8^{\star} \pm 4.3$ & $<25$ \\
\hline Camellia sinensis (L.) KUNTZE (Assam) & Leaf & $11: 1$ & 0.1 & $<25$ & n.d. \\
\hline Camellia sinensis (L.) KUNTZE (Darjeeling) & Leaf & $5: 1$ & 0.1 & $<25$ & n.d. \\
\hline Camellia sinensis (L.) KUNTZE (gunpowder) & Leaf & $5: 1$ & 0.1 & $<25$ & n.d. \\
\hline Camellia sinensis (L.) KUNTZE (Sencha) & Leaf & $5: 1$ & 0.1 & $<25$ & n.d. \\
\hline Ceratonia siliqua L. & Fruit & $4: 1$ & 1 & $<25$ & n.d. \\
\hline Citrus limon (L.) OSBECK & Fruit skin & $7: 1$ & 0.1 & $<25$ & n.d. \\
\hline Coffea arabica L. & Green seed & $7: 1$ & 1 & $<25$ & n.d. \\
\hline Cornus officinalis SIEBOLD and zUCC. & Fruit & $3: 1$ & 1 & $73.8^{\star} \pm 6.7$ & $<25$ \\
\hline Crataegus pinnatifida BUNGE & Fruit & n.d. & 1 & $73.7^{\star} \pm 4.2$ & $<25$ \\
\hline Cynara cardunculus L. & Herb & n.d. & 0.1 & $<25$ & n.d. \\
\hline Eucommia ulmoides oLIV. & Bark & n.d. & 0.1 & $<30$ & n.d. \\
\hline Hibiscus sabdariffa L. & Flower & $4: 1$ & 0.1 & $<25$ & n.d. \\
\hline Ilex paraguariensis A. ST.-HIL & Leaf & $7: 1$ & 0.1 & $<25$ & n.d. \\
\hline Juglans regia L. & Leaf & $12: 1$ & 1 & $52.4^{*} \pm 1.7$ & $30.2^{\star} \pm 11.7$ \\
\hline Lycium chinense MILL. & Fruit & n.d. & 1 & $75.2^{\star} \pm 0.5$ & $<25$ \\
\hline Melissa officinalis L. & Leaf & n.d. & 0.1 & $<25$ & n.d. \\
\hline Mentha aquatica L. & Leaf & $16: 1$ & 0.1 & $<25$ & n.d. \\
\hline Momordica charantia L. & Fruit & $13: 1$ & 0.1 & $<25$ & n.d. \\
\hline Nigella sativa L. & Seed & $14: 1$ & 0.1 & $<25$ & n.d. \\
\hline Olea europaea L. & Leaf & $5: 1$ & 0.1 & $<25$ & n.d. \\
\hline Origanum creticum L. & Leaf & $16: 1$ & 0.1 & $<25$ & n.d. \\
\hline Panax ginseng C.A. MEY & Root & $9: 1$ & 0.1 & $<25$ & n.d. \\
\hline Peumus boldus MOLINA & Leaf & $5: 1$ & 1 & $47.5^{\star} \pm 7.5$ & $32.6^{\star} \pm 26.1$ \\
\hline Potentilla aurea L & Herb & $15: 1$ & 1 & $<25$ & n.d. \\
\hline Pueraria lobata (WILLD.) OHWI & Root & $6: 1$ & 0.1 & $<25$ & n.d. \\
\hline Rosa rugosa THunB. & Flower & $6: 1$ & 0.1 & $<25$ & n.d. \\
\hline Rosmarinus officinalis L. & Leaf & $6: 1$ & 0.1 & $<25$ & n.d. \\
\hline Salvia officinalis L. & Leaf & $9: 1$ & 0.1 & $<25$ & n.d. \\
\hline Sarcopoterium spinosum (L.) SPACH & Root & $14: 1$ & 0.1 & $<25$ & n.d. \\
\hline Syzygium aromaticum (L.) MERR. and L.M.PERRY & Flower & $17: 1$ & 0.1 & $<25$ & n.d. \\
\hline Thymus vulgaris $\mathrm{L}$. & Herb & $14: 1$ & 0.1 & $<25$ & n.d. \\
\hline Vaccinium myrtillus L. & Fruit & $2: 1$ & 1 & $79.9^{\star} \pm 1.1$ & $<25$ \\
\hline Vitis vinifera $\mathrm{L}$. & Seed (pomace) & $15: 1$ & 1 & $<25$ & n.d. \\
\hline
\end{tabular}

inhibition: 64.6\%) indicated a strong and reproducible inhibitory potential between 40 and $80 \%$ on intestinal glucose transporters as visualized in Figure 1. Seven of these extracts showed higher uptake inhibition rates than the two controls phloretin (uptake inhibition: 60.4\%) and phlorizin (uptake inhibition: 55.1\%). A queous extracts made from the bark of Eucommia ulmoides (uptake inhibition: 68.7\%) and the fruits of Malus domestica (uptake inhibition: 57.5\%) inhibited glucose uptake significantly and reproducibly. Additionally, for the methanolic extract of Brassica oleracea and the aqueous extract of Eucommia ulmoides, IC $_{50}$ was calculated as 0.0904 and $0.4285 \mathrm{mg} / \mathrm{ml}$, respectively. These extracts decreased glucose uptake in a dose-dependent manner. The methanolic extracts of Juglans regia (uptake inhibition: $30.2 \%$ ) and Peumus boldus (uptake inhibition: $32.6 \%$ ) inhibited the fructose uptake significantly.

\section{DISCUSSION}

According to the results of the present study, the observed hypoglycemic effects in animal and/or human studies after treatment with preparations of Adenophora triphylla, Aronia melanocarpa, Brassica oleracea, Cornus officinalis, Crataegus pinnatifida, Eucommia ulmoides, Juglans regia, Lycium chinense, Malus domestica, Peumus boldus, and Vaccinium myrtillus as listed in Table 1 possibly relate to the inhibition of intestinal transporters. The methanolic plant extracts made from the leaves of Juglans regia and Peumus boldus decreased glucose as well as fructose uptake possibly related to inhibition of GLUT2, which is able to transport both monosaccharides. These findings show that the traditional use of Brassica oleracea, Cornus officinalis, Eucommia ulmoides, Juglans regia, Lycium chinense, Malus domestica, and Vaccinium myrtillus and their preparations 
TABLE 3 | Results of glucose and fructose uptake studies with aqueous extracts, the used plant part, drug extract ratio, and tested concentration, which did not show any influence on cells in MTT assay. Only the plants that showed the strongest inhibition rates on glucose uptake were tested for fructose uptake inhibition. Regarding methanolic and aqueous extracts, the extract of a plant that showed the stronger inhibition on glucose absorption was repeated and tested for its impact on fructose uptake; mean value \pm SD; *significant difference in $U$-test $(n=2-3 ; 12$ replicates each; two-sided; $\alpha=0.05)$; n.d. $=$ not determined.

\begin{tabular}{|c|c|c|c|c|c|}
\hline $\begin{array}{l}\text { Scientific plant } \\
\text { name }\end{array}$ & $\begin{array}{l}\text { Used part } \\
\text { of the } \\
\text { plant }\end{array}$ & $\begin{array}{l}\text { Drug extract } \\
\text { ratio for } \\
\text { aqueous extracts }\end{array}$ & $\begin{array}{c}\text { Used aqueous } \\
\text { extract concentration } \\
\text { in } \mathrm{mg} / \mathrm{mL}\end{array}$ & $\begin{array}{l}\text { Uptake inhibition } \\
\text { of glucose } \\
\text { in } \%\end{array}$ & $\begin{array}{l}\text { Uptake inhibition } \\
\text { of fructose } \\
\text { in } \%\end{array}$ \\
\hline Adenophora triphylla (THUNB.) ADC. & Root & n.d. & 1 & $<40$ & n.d. \\
\hline Allium sativum L. & Bulb & $2: 1$ & 1 & $<50$ & n.d. \\
\hline Aronia melanocarpa MICHX. ELLIOTT & Fruit & $3: 1$ & 1 & $<60$ & n.d. \\
\hline Artemisia dracunculus L. & Leaf & $5: 1$ & 1 & $<25$ & n.d. \\
\hline Brassica oleracea L. "Capitata alba" & Leaf & $2: 1$ & 0.1 & $<60$ & n.d. \\
\hline Camellia sinensis (L.) KUNTZE (Assam) & Leaf & $6: 1$ & 0.1 & $<25$ & n.d. \\
\hline Camellia sinensis (L.) KUNTZE (Darjeeling) & Leaf & $7: 1$ & 0.1 & $<25$ & n.d. \\
\hline Camellia sinensis (L.) KUNTZE (gunpowder) & Leaf & $5: 1$ & 0.1 & $<25$ & n.d. \\
\hline Camellia sinensis (L.) KUNTZE (sencha) & Leaf & $6: 1$ & 0.1 & $<25$ & n.d. \\
\hline Ceratonia siliqua L. & Fruit & $3: 1$ & 1 & $<25$ & n.d. \\
\hline Citrus limon (L.) OSBECK & Fruit skin & $4: 1$ & 1 & $<40$ & n.d. \\
\hline Coffea arabica L. & Green seed & $5: 1$ & 1 & $<25$ & n.d. \\
\hline Cornus officinalis SIEBOLD and zucc. & Fruit & n.d. & 1 & $<65$ & n.d. \\
\hline Crataegus pinnatifida BUNGE & Fruit & n.d. & 1 & $<60$ & n.d. \\
\hline Cuminum cyminum L. & Seed & $5: 1$ & 0.1 & $<25$ & n.d. \\
\hline Cynara cardunculus L. & Herb & $3: 1$ & 0.1 & $<30$ & n.d. \\
\hline Eucommia ulmoides oLIV. & Bark & $16: 1$ & 1 & $68.7^{\star} \pm 13.2$ & $<25$ \\
\hline Hibiscus sabdariffa L. & Flower & $2: 1$ & 0.1 & $<25$ & n.d. \\
\hline Ilex paraguariensis A. ST.-HIL & Leaf & $5: 1$ & 0.1 & $<25$ & n.d. \\
\hline Juglans regia L. & Leaf & $7: 1$ & 1 & $<25$ & n.d. \\
\hline Lycium chinense MILL. & Fruit & $3: 1$ & 1 & $<75$ & n.d. \\
\hline Malus domestica воRKH. "Gold en delicious" & Fruit skin & $3: 1$ & 1 & $57.5^{\star} \pm 9.2$ & $<25$ \\
\hline Melissa officinalis L. & Leaf & $4: 1$ & 0.01 & $<25$ & n.d. \\
\hline Mentha aquatica L. & Leaf & $6: 1$ & 1 & $<40$ & n.d. \\
\hline Momordica charantia L. & Fruit & $6: 1$ & 1 & $<25$ & n.d. \\
\hline Nigella sativa L. & Seed & $4: 1$ & 0.1 & $<25$ & n.d. \\
\hline Olea europaea L. & Leaf & $5: 1$ & 1 & $<25$ & n.d. \\
\hline Origanum creticum L. & Leaf & $4: 1$ & 0.1 & $<25$ & n.d. \\
\hline Panax ginseng C.A. MEY & Root & $3: 1$ & 1 & $<25$ & n.d. \\
\hline Peumus boldus MOLINA & Leaf & n.d & 1 & $<40$ & n.d. \\
\hline Potentilla aurea L. & Herb & $8: 1$ & 0.1 & $<25$ & n.d. \\
\hline Pueraria lobata (WILLD.) OHWI & Root & $4: 1$ & 1 & $<50$ & n.d. \\
\hline Punica granatum L. & Fruit skin & $3: 1$ & 0.1 & $<25$ & n.d. \\
\hline Rosa rugosa THUNB. & Flower & n.d & 0.1 & $<30$ & n.d. \\
\hline Rosmarinus officinalis L. & Leaf & $5: 1$ & 0.1 & $<25$ & n.d. \\
\hline Salvia officinalis L. & Leaf & $5: 1$ & 0.1 & $<25$ & n.d. \\
\hline Sarcopoterium spinosum (L.) SPACH & Root & $28: 1$ & 1 & $<25$ & n.d. \\
\hline Syzygium aromaticum (L.) MERR. and L.M.PERRY & Flower & n.d. & 0.1 & $<25$ & n.d. \\
\hline Thymus vulgaris $\mathrm{L}$. & Herb & $6: 1$ & 1 & $<25$ & n.d. \\
\hline Vaccinium myrtillus L. & Fruit & $2: 1$ & 1 & $<80$ & n.d. \\
\hline Vitis vinifera $\mathrm{L}$. & Seed (pomace) & $27: 1$ & 1 & $<40$ & n.d. \\
\hline
\end{tabular}

as antidiabetic remedy and adjuncts to conventional treatments in the therapy of Diabetes mellitus is reasonable. Extracts of these plants show inhibitory activity on intestinal glucose and fructose transporters resulting in lower blood concentrations of the monosaccharides and reduced concomitant health problems.

In literature, there is not much comparable data available, because the inhibition of intestinal transporters by crude plant extracts in Caco2 cells has not been investigated very well (Schreck and Melzig, 2018). Kim et al. determined a moderate inhibition of glucose uptake in $\mathrm{Caco} 2$ cells for methanolic extracts of Adenophora triphylla (uptake inhibition: 13.4\%) and Cornus officinalis (uptake inhibition: 16.4\%), but other results as for Crataegus pinnatifida (no uptake inhibition) are not consistent with our findings (Kim et al., 2011). Zhang et al. confirmed an uptake inhibition of $26.3 \%$ for Eucommia ulmoides (Zhang et al., 2015). Manzano et al. only tested specific polyphenol-rich fractions of Malus domestica (Manzano and Williamson, 2010), which showed inhibitory activity on intestinal glucose transporters, but it is not directly comparable with our work. Discrepancies between results from different studies probably depend on different preparations of the extracts, the use of modified substrates, and/or an insufficient validation of the cell model. We determined the expression of relevant transporters over three weeks in $\mathrm{Caco} 2$ cells and adapted our experimental settings in accordance with the ensured presence of functional transporters (Schreck and Melzig, 2019). Buchholz 


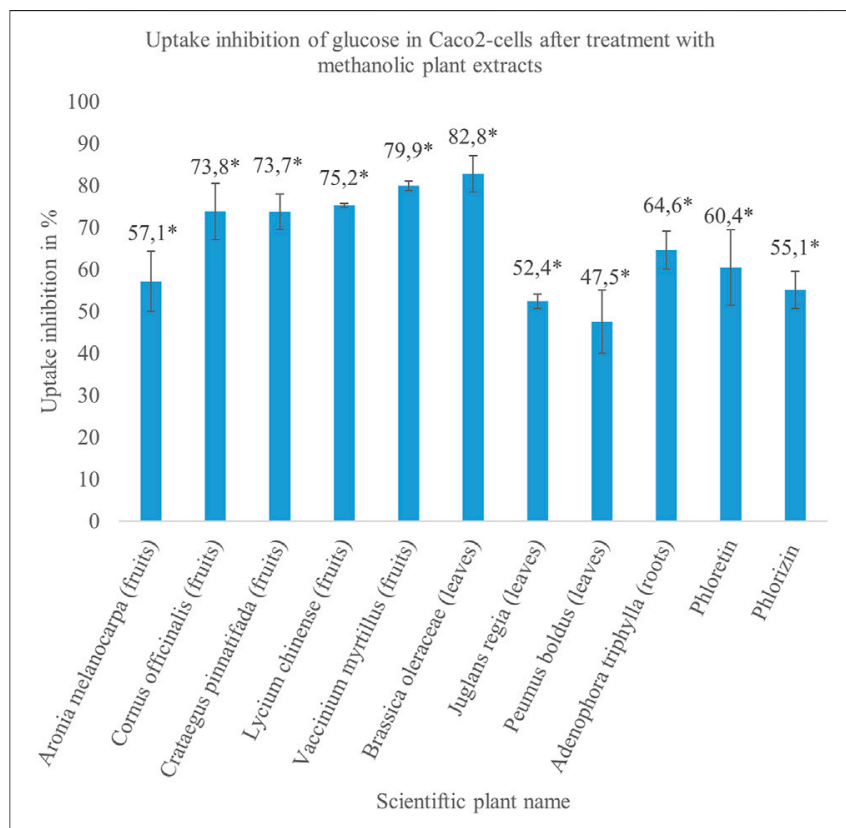

FIGURE 1 | The results of the methanolic plant extracts, which reduced glucose uptake between 40 and $80 \%$ in treated cells significantly compared to untreated cells in a concentration of $1 \mathrm{mg} / \mathrm{ml}$. The extracts were made from different parts of the plants enclosed in brackets. The solutions of $100 \mu \mathrm{M}$ phloretin and $100 \mu \mathrm{M}$ phlorizin were used as positive controls and inhibited glucose uptake in Caco2 cells by approximately $60 \%$. The illustrated results refer to the data in Table 2. Mean value \pm SD. * Significant difference in $U$-test ( $n=2$ with 12 replicates each; two-sided, $\alpha=0.05$ ).

et al. examined whether extracts of the traditionally used plants inhibit cleavage of polysaccharides and lipids by affecting lipase and $\alpha$-amylase activity (Prasain et al., 2012). The methanolic extracts of Aronia melanocarpa, Peumus boldus, and Vaccinium myrtillus showed strong lipase and $\alpha$-amylase inhibition as well as inhibition of intestinal monosaccharide transporters in our studies. This multi-target effect of the mentioned plant preparations describes a partial, but multiple drug action and is proposed to exceed drugs with single-target effects. Based on synergistic mechanisms, the plants that affect various targets to alleviate monosaccharide uptake show therapeutic advantages concerning higher intended and lower adverse effects (Csermely et al., 2005). Since the plants, especially the fruits, contain sugars themselves, it cannot be totally excluded that a part of the inhibition is a "pseudo-inhibition" and comes from the displacement of the radioactive substrates by non-radioactive

\section{REFERENCES}

Al-Aboudi, A., and Afifi, F. U. (2011). Plants Used for the Treatment of Diabetes in jordan: A Review of Scientific Evidence. Pharm. Biol. 49, 221-239. doi:10.3109/ 13880209.2010.501802

American Diabetes Association (2014). Diagnosis and Classification of Diabetes Mellitus. Diabetes Care 37, 81-90.

Asadi, A., Shidfar, F., Safari, M., Hosseini, A. F., Fallah Huseini, H., Heidari, I., et al. (2019). Efficacy of Melissa Officinalis L. (Lemon Balm) Extract on Glycemic Control and Cardiovascular Risk Factors in Individuals with Type 2 Diabetes: A monosaccharides during absorption processes. For this reason, the focus of this work was on methanolic extracts that naturally contain fewer monosaccharides. Commonly, the discussed constituents of the plants with inhibitory effects on intestinal transporters are polyphenolic compounds as shown in Table 1. Particularly, the chalcones phlorizin and phloretin (Debnam and Levin, 1975; Zheng et al., 2012; Raja and Kinne, 2015), which are often used as positive controls in transport studies, the flavonoids quercetin, fisetin, and myricetin (Kwon et al., 2007) and the tannins (-)-epigallocatechin gallate, (-)-epigallocatechin, and (-)-epicatechin gallate seem to act as inhibitors of intestinal, monosaccharide transporters (Johnston et al., 2005). Further studies are planned to investigate which fraction of the extracts, or more specifically, which group of compounds are responsible for the inhibition of the intestinal glucose and fructose transporters in this study.

\section{DATA AVAILABILITY STATEMENT}

The original contributions presented in the study are included in the article/Supplementary Material, and further inquiries can be directed to the corresponding author.

\section{AUTHOR CONTRIBUTIONS}

KS designed the studies, performed experiments, analyzed the data, and drafted the manuscript. MM supervised the performance of the experiments and interpretation of the data. MM proofread the manuscript.

\section{ACKNOWLEDGMENTS}

We would like to thank Yi Gu for screening the plants in the MTT assay according to our protocol. We acknowledge the support from the Open Access Publication Fund of the Freie Universitaet Berlin.

\section{SUPPLEMENTARY MATERIAL}

The Supplementary Material for this article can be found online at: https://www.frontiersin.org/articles/10.3389/fphar.2021.692566/ full\#supplementary-material

Randomized, Double-Blind, Clinical Trial. Phytother Res. 33, 651-659. doi: $10.1002 /$ ptr.6254

Assad, T., Khan, R. A., and Feroz, Z. (2014). Evaluation of Hypoglycemic and Hypolipidemic Activity of Methanol Extract of brassica Oleracea. Chin. J. Nat. Medicines 12, 648-653. doi:10.1016/s1875-5364(14)60099-6

Bachrach, Z. Y. (2007). Ethnobotanical Studies of Sarcopoterium Spinosum in israel. Isr. J. Plant Sci. 55, 111-114. doi:10.1560/ijps.55.1.111

Bagri, P., Ali, M., Aeri, V., Bhowmik, M., and Sultana, S. (2009). Antidiabetic Effect of Punica Granatum Flowers: Effect on Hyperlipidemia, Pancreatic Cells Lipid Peroxidation and Antioxidant Enzymes in Experimental Diabetes. Food Chem. Toxicol. 47, 50-54. doi:10.1016/j.fct.2008.09.058 
Bahadoran, Z., Mirmiran, P., and Azizi, F. (2013). Dietary Polyphenols as Potential Nutraceuticals in Management of Diabetes: A Review. J. Diabetes Metab. Disord. 12, 43. doi:10.1186/2251-6581-12-43

Bakırel, T., Bakırel, U., Keleş, O. Ü., Ülgen, S. G., and Yardibi, H. (2008). In Vivo assessment of Antidiabetic and Antioxidant Activities of Rosemary (Rosmarinus Officinalis) in Alloxan-Diabetic Rabbits. J. Ethnopharmacology 116, 64-73.

Bamosa, A. O., Kaatabi, H., Lebdaa, F. M., Elq, A. M., and Al-Sultanb, A. (2010). Effect of Nigella Sativa Seeds on the Glycemic Control of Patients with Type 2 Diabetes Mellitus. Indian J. Physiol. Pharmacol. 54, 344-354.

Banjari, I., Misir, A., Šavikin, K., Jokić, S., Molnar, M., De Zoysa, H. K. S., et al. (2017). Antidiabetic Effects of Aronia Melanocarpa and its Other Therapeutic Properties. Front. Nutr. 4, 53. doi:10.3389/fnut.2017.00053

Behradmanesh, S., Derees, F., and Rafieian-Kopaei, M. (2013). Effect of Salvia Officinalis on Diabetic Patients. J. Ren. Inj Prev 2, 51-54. doi:10.12861/ jrip. 2013.18

Buchholz, T. (2017). "Secondary Metabolites as Inhibitors of Selected Digestive Enzymes," (Freie Universitaet Berlin). Thesis.

Buchholz, T., and Melzig, M. F. (2016). Medicinal Plants Traditionally Used for Treatment of Obesity and Diabetes Mellitus - Screening for Pancreatic Lipase and a-Amylase Inhibition. Phytother. Res. 30, 260-266. doi:10.1002/ptr.5525

Campos-Florian, J., Bardales-Valdivia, J., Caruajulca-Guevara, L., and CuevaLlanos, D. (2013). Anti-diabetic Effect of Coffea Arabica, in AlloxanInduced Diabetic Rats. Emirates J. Food Agric. 25, 772.

Chantret, I., Barbat, A., Dussaulx, E., Brattain, M. G., and Zweibaum, A. (1988). Epithelial Polarity, Villin Expression, and Enterocytic Differentiation of Cultured Human colon Carcinoma Cells: A Survey of Twenty Cell Lines. Cancer Res. 48, 1936-1942.

Csermely, P., Ágoston, V., and Pongor, S. (2005). The Efficiency of Multi-Target Drugs: The Network Approach Might Help Drug Design. Trends Pharmacol. Sci. 26, 178-182. doi:10.1016/j.tips.2005.02.007

de Freitas Junior, L. M., and de Almeida, E. B., Jr. (2017). Medicinal Plants for the Treatment of Obesity: Ethnopharmacological Approach and Chemical and Biological Studies. Am. J. Transl Res. 9, 2050-2064.

Debnam, E. S., and Levin, R. J. (1975). An Experimental Method of Identifying and Quantifying the Active Transfer Electrogenic Component from the Diffusive Component during Sugar Absorption Measured In Vivo. J. Physiol. 246, 181-196. doi:10.1113/jphysiol.1975.sp010885

Dehghani, S., Mehri, S., and Hosseinzadeh, H. (2019). The Effects of Crataegus Pinnatifida (Chinese Hawthorn) on Metabolic Syndrome: A Review. Iran J. Basic Med. Sci. 22, 460-468. doi:10.22038/IJBMS.2019.31964.7678

Eidi, A., and Eidi, M. (2009). Antidiabetic Effects of Sage (Salvia Officinalis 1.) Leaves in normal and Streptozotocin-Induced Diabetic Rats. Diabetes Metab. Syndr. Clin. Res. Rev. 3, 40-44. doi:10.1016/j.dsx.2008.10.007

Eidi, A., Eidi, M., and Darzi, R. (2009). Antidiabetic Effect ofOlea europaeaL. In normal and Diabetic Rats. Phytother. Res. 23, 347-350. doi:10.1002/ptr.2629

Eidi, A., Eidi, M., and Esmaeili, E. (2006). Antidiabetic Effect of Garlic (Allium Sativum 1.) in normal and Streptozotocin-Induced Diabetic Rats. Phytomedicine 13, 624-629. doi:10.1016/j.phymed.2005.09.010

Ekoh, S. N., Akubugwo, I. E., Ude, V. C., and Edwin, N. (2014). Anti-hyperglycemic and Anti-hyperlipidemic Effect of Spices (Thymus Vulgaris, Murraya Koenigii, Ocimum Gratissimum and Piper Guineense) in Alloxan-Induced Diabetic Rats. Int. J. Biosciences 4, 179-187.

Elyasiyan, U., Nudel, A., Skalka, N., Rozenberg, K., Drori, E., Oppenheimer, R., et al. (2017). Anti-diabetic Activity of Aerial Parts of Sarcopoterium Spinosum. BMC Complement. Altern. Med. 17, 356. doi:10.1186/s12906-017-1860-7

Fabricant, D. S., and Farnsworth, N. R. (2001). The Value of Plants Used in Traditional Medicine for Drug Discovery. Environ. Health Perspect. 109, 69-75. doi:10.1289/ehp.01109s169

Gilani, A. H., Rahman, U.-A., and Trends, R. (2005). Trends in Ethnopharmacology. J. Ethnopharmacology 100, 43-49. doi:10.1016/j.jep.2005.06.001

Gomes, A., Vedasiromoni, J. R., Das, M., Sharma, R. M., and Ganguly, D. K. (1995). Anti-hyperglycemic Effect of Black tea (Camellia Sinensis) in Rat. J. Ethnopharmacology 45, 223-226. doi:10.1016/0378-8741(95)01223-z

Grover, J. K., and Yadav, S. P. (2004). Pharmacological Actions and Potential Uses of Momordica Charantia: A Review. J. Ethnopharmacology 93, 123-132. doi:10.1016/j.jep.2004.03.035

Grundy, S. M. (1998). Multifactorial Causation of Obesity: Implications for Prevention. Am. J. Clin. Nutr. 67, 563S-572S. doi:10.1093/ajen/67.3.563s
Han, Q., Yu, Q.-Y., Shi, J., Xiong, C.-Y., Ling, Z.-J., and He, P.-M. (2011). Molecular Characterization and Hypoglycemic Activity of a Novel Water-Soluble Polysaccharide from tea (Camellia Sinensis) Flower. Carbohydr. Polym. 86, 797-805. doi:10.1016/j.carbpol.2011.05.039

Hanhineva, K., Törrönen, R., Bondia-Pons, I., Pekkinen, J., Kolehmainen, M., Mykkänen, H., et al. (2010). Impact of Dietary Polyphenols on Carbohydrate Metabolism. Int. J. Mol. Sci. 11, 1365-1402. doi:10.3390/ijms11041365

Hasanein, P., and Riahi, H. (2015). Antinociceptive and Antihyperglycemic Effects of Melissa Officinalis Essential Oil in an Experimental Model of Diabetes. Med. Princ Pract. 24, 47-52. doi:10.1159/000368755

He, K., Song, S., Zou, Z., Feng, M., Wang, D., Wang, Y., et al. (2016). The Hypoglycemic and Synergistic Effect of Loganin, Morroniside, and Ursolic Acid Isolated from the Fruits of Cornus Officinalis. Phytother. Res. 30, 283-291. doi:10.1002/ptr.5529

He, X., Wang, J., Li, M., Hao, D., Yang, Y., Zhang, C., et al. (2014). Eucommia Ulmoides oliv.: Ethnopharmacology, Phytochemistry and Pharmacology of an Important Traditional Chinese Medicine. J. Ethnopharmacology 151, 78-92. doi:10.1016/j.jep.2013.11.023

Heidarian, E., and Soofiniya, Y. (2011). Hypolipidemic and Hypoglycemic Effects of Aerial Part of Cynara Scolymus in Streptozotocin-Induced Diabetic Rats. J. Med. Plants Res. 5, 2717-2723.

Helmstaedter, A. (2007). Antidiabetic Drugs Used in Europe Prior to the Discovery of Insulin. Die Pharmazie 62, 717-720.

Hidalgo, I. J., Raub, T. J., and Borchardt, R. T. (1989). Characterization of the Human colon Carcinoma Cell Line (Caco-2) as a Model System for Intestinal Epithelial Permeability. Gastroenterology 96, 736-749. doi:10.1016/s0016-5085(89)80072-1

Hogan, S., Zhang, L., Li, J., Sun, S., Canning, C., and Zhou, K. (2010). Antioxidant Rich Grape Pomace Extract Suppresses Postprandial Hyperglycemia in Diabetic Mice by Specifically Inhibiting Alpha-Glucosidase. Nutr. Metab. 7, 71. doi:10.1186/1743-7075-7-71

Hosseini, S., Jamshidi, L., Mehrzadi, S., Mohammad, K., Najmizadeh, A. R., Alimoradi, H., et al. (2014). Effects of Juglans Regia L. Leaf Extract on Hyperglycemia and Lipid Profiles in Type Two Diabetic Patients: A Randomized Double-Blind, Placebo-Controlled Clinical Trial. J. Ethnopharmacology 152, 451-456. doi:10.1016/j.jep.2014.01.012

Idm'hand, E., Msanda, F., and Cherifi, K. (2020). Ethnopharmacological Review of Medicinal Plants Used to Manage Diabetes in morocco. Clin. Phytoscience 6, 18.

Jagtap, A. G., and Patil, P. B. (2010). Antihyperglycemic Activity and Inhibition of Advanced Glycation End Product Formation by Cuminum Cyminum in Streptozotocin Induced Diabetic Rats. Food Chem. Toxicol. 48, 2030-2036. doi:10.1016/j.fct.2010.04.048

Jang, Y. Y., Song, J. H., Shin, Y. K., Han, E. S., and Lee, C. S. (2000). Protective Effect of Boldine on Oxidative Mitochondrial Damage in Streptozotocin-Induced Diabetic Rats. Pharmacol. Res. 42, 361-371. doi:10.1006/phrs.2000.0705

Johnston, K., Sharp, P., Clifford, M., and Morgan, L. (2005). Dietary Polyphenols Decrease Glucose Uptake by Human Intestinal Caco-2 Cells. FEBS Lett. 579, 1653-1657. doi:10.1016/j.febslet.2004.12.099

Jumarie, C., and Malo, C. (1991). Caco-2 Cells Cultured in Serum-free Medium as a Model for the Study of Enterocytic Differentiation In Vitro. J. Cel. Physiol. 149, 24-33. doi:10.1002/jcp.1041490105

Kang, Y.-R., Lee, H.-Y., Kim, J.-H., Moon, D.-I., Seo, M.-Y., Park, S.-H., et al. (2012). Anti-obesity and Anti-diabetic Effects of Yerba Mate (ilex Paraguariensis) in C57bl/6j Mice Fed a High-Fat Diet. Lab. Anim. Res. 28, 23-29. doi:10.5625/lar.2012.28.1.23

Kataya, H. A. H., and Hamza, A. A. (2008). Red Cabbage (brassica Oleracea) Ameliorates Diabetic Nephropathy in Rats. Evidence-Based Complement. Altern. Med. 5, 281-287. doi:10.1093/ecam/nem029

Katemo, M., Mpiana, P. T., Mbala, B. M., Mihigo, S. O., Ngbolua, K. N., Tshibangu, D. S. T., et al. (2012). Ethnopharmacological Survey of Plants Used against Diabetes in Kisangani City (Dr congo). J. Ethnopharmacology 144, 39-43. doi:10.1016/j.jep.2012.08.022

Khathi, A., Serumula, M. R., Myburg, R. B., Van Heerden, F. R., and Musabayane, C. T. (2013). Effects of Syzygium Aromaticum-Derived Triterpenes on Postprandial Blood Glucose in Streptozotocin-Induced Diabetic Rats Following Carbohydrate challenge. PloS one 8, e81632. doi:10.1371/journal.pone.0081632

Kim, H. K., Baek, S.-S., and Cho, H.-Y. (2011). Inhibitory Effect of Pomegranate on Intestinal Sodium Dependent Glucose Uptake. Am. J. Chin. Med. 39, 1015-1027. doi:10.1142/s0192415x11009378 
Kim, H. Y., Moon, B. H., Lee, H. J., and Choi, D. H. (2004). Flavonol Glycosides from the Leaves of Eucommia Ulmoides O. With Glycation Inhibitory Activity. J. ethnopharmacology 93, 227-230. doi:10.1016/j.jep.2004.03.047

Kwon, O., Eck, P., Chen, S., Corpe, C. P., Lee, J. H., Kruhlak, M., et al. (2007). Inhibition of the Intestinal Glucose Transporter Glut2 by Flavonoids. FASEB $j$. 21, 366-377. doi:10.1096/fi.06-6620com

Lee, M.-K., Kim, M.-J., Cho, S.-Y., Park, S. A., Park, K.-K., Jung, U. J., et al. (2005). Hypoglycemic Effect of Du-Zhong (Eucommia Ulmoides oliv.) Leaves in Streptozotocin-Induced Diabetic Rats. Diabetes Res. Clin. Pract. 67, 22-28. doi:10.1016/j.diabres.2004.05.013

Lee, Y.-H., Jung, M. G., Kang, H. B., Choi, K.-C., Haam, S., Jun, W., et al. (2008). Effect of Anti-histone Acetyltransferase Activity from Rosa Rugosa Thunb. (Rosaceae) Extracts on Androgen Receptor-Mediated Transcriptional Regulation. J. Ethnopharmacology 118, 412-417. doi:10.1016/ j.jep.2008.05.006

Li, W. L., Zheng, H. C., Bukuru, J., and De Kimpe, N. (2004). Natural Medicines Used in the Traditional Chinese Medical System for Therapy of Diabetes Mellitus. J. Ethnopharmacology 92, 1-21. doi:10.1016/j.jep.2003.12.031

Liu, L., Tang, D., Zhao, H., Xin, X., and Aisa, H. A. (2017). Hypoglycemic Effect of the Polyphenols Rich Extract from Rose Rugosa Thunb on High Fat Diet and Stz Induced Diabetic Rats. J. Ethnopharmacology 200, 174-181. doi:10.1016/ j.jep.2017.02.022

Ma, W., Wang, K.-J., Cheng, C.-S., Yan, G.-q., Lu, W.-L., Ge, J.-F., et al. (2014). Bioactive Compounds from Cornus Officinalis Fruits and Their Effects on Diabetic Nephropathy. J. Ethnopharmacology 153, 840-845. doi:10.1016/ j.jep.2014.03.051

Maljaars, P. W. J., Peters, H. P. F., Mela, D. J., and Masclee, A. A. M. (2008). Ileal Brake: A Sensible Food Target for Appetite Control. A Review. Physiol. Behav. 95, 271-281. doi:10.1016/j.physbeh.2008.07.018

Manzano, S., and Williamson, G. (2010). Polyphenols and Phenolic Acids from Strawberry and Apple Decrease Glucose Uptake and Transport by Human Intestinal Caco-2 Cells. Mol. Nutr. Food Res. 54, 1773-1780. doi:10.1002/ mnfr.201000019

Naim, M., Amjad, F. M., Sultana, S., Islam, S. N., Hossain, M. A., Begum, R., et al. (2012). Comparative Study of Antidiabetic Activity of Hexane-Extract of Lemon Peel (limon Citrus) and Glimepiride in Alloxan-Induced Diabetic Rats. Bangla Pharma J. 15, 131-134. doi:10.3329/bpj.v15i2.12577

Nazni, P., Vijayakumar, T. P., Alagianambi, P., and Amirthaveni, M. (2006). Hypoglycemic and Hypolipidemic Effect of Cynara Scolymus Among Selected Type 2 Diabetic Individuals. Pakistan J. Nutr. 5, 147-151.

Neves, J. M., Matos, C., Moutinho, C., Queiroz, G., and Gomes, L. R. (2009). Ethnopharmacological Notes about Ancient Uses of Medicinal Plants in TrásOs-Montes (Northern of Portugal). J. Ethnopharmacology 124, 270-283. doi:10.1016/j.jep.2009.04.041

Olatunji, O. J., Chen, H., and Zhou, Y. (2017). Effect of the Polyphenol Rich Ethyl Acetate Fraction from the Leaves of Lycium Chinensemill. On Oxidative Stress, Dyslipidemia, and Diabetes Mellitus in Streptozotocin-Nicotinamide Induced Diabetic Rats. Chem. biodiversity 14, e1700277. doi:10.1002/cbdv.201700277

Ota, A., and Ulrih, N. P. (2017). An Overview of Herbal Products and Secondary Metabolites Used for Management of Type Two Diabetes. Front. Pharmacol. 8, 436. doi:10.3389/fphar.2017.00436

Park, S. A., Choi, M.-S., Kim, M.-J., Jung, U. J., Kim, H.-J., Park, K.-K., et al. (2006). Hypoglycemic and Hypolipidemic Action of Du-Zhong (Eucommia Ulmoides Oliver) Leaves Water Extract in C57bl/ksj-Db/db Mice. J. Ethnopharmacology 107, 412-417. doi:10.1016/j.jep.2006.03.034

Park, S. J., Nam, J., Ahn, C. W., and Kim, Y. (2019). Anti-diabetic Properties of Different Fractions of Korean Red Ginseng. J. Ethnopharmacology 236, 220-230. doi:10.1016/j.jep.2019.01.044

Peng, C.-H., Chyau, C.-C., Chan, K.-C., Chan, T.-H., Wang, C.-J., and Huang, C.N. (2011). Hibiscus sabdariffaPolyphenolic Extract Inhibits Hyperglycemia, Hyperlipidemia, and Glycation-Oxidative Stress while Improving Insulin Resistance. J. Agric. Food Chem. 59, 9901-9909. doi:10.1021/jf2022379

Prasain, J. K., Peng, N., Rajbhandari, R., and Wyss, J. M. (2012). The Chinese Pueraria Root Extract (Pueraria Lobata) Ameliorates Impaired Glucose and Lipid Metabolism in Obese Mice. Phytomedicine 20, 17-23. doi:10.1016/ j.phymed.2012.09.017

Prasanna, R., Ashraf, E. A., and Essam, M. A. (2017). Chamomile and Oregano Extracts Synergistically Exhibit Antihyperglycemic, Antihyperlipidemic, and
Renal Protective Effects in Alloxan-Induced Diabetic Rats. Can. J. Physiol. Pharmacol. 95, 84-92. doi:10.1139/cjpp-2016-0189

Raja, M., and Kinne, R. K. H. (2015). Identification of Phlorizin Binding Domains in Sodium-Glucose Cotransporter Family: Sglt1 as a Unique Model System. Biochimie 115, 187-193. doi:10.1016/j.biochi.2015.06.003

Ribnicky, D. M., Poulev, A., Watford, M., Cefalu, W. T., and Raskin, I. (2006). Antihyperglycemic Activity of Tarralin, an Ethanolic Extract of Artemisia Dracunculus L. Phytomedicine 13, 550-557. doi:10.1016/j.phymed.2005.09.007

Rizvi, S. I., and Mishra, N. (2013). Traditional Indian Medicines Used for the Management of Diabetes Mellitus. J. Diabetes Res. 2013, 712092. doi:10.1155/ 2013/712092

Rtibi, K., Selmi, S., Grami, D., Amri, M., Eto, B., El-benna, J., et al. (2017). Chemical Constituents and Pharmacological Actions of Carob Pods and Leaves (Ceratonia Siliqua 1.) on the Gastrointestinal Tract: A Review. Biomed. Pharmacother. 93, 522-528. doi:10.1016/j.biopha.2017.06.088

Sambuy, Y., De Angelis, I., Ranaldi, G., Scarino, M. L., Stammati, A., and Zucco, F. (2005). The Caco-2 Cell Line as a Model of the Intestinal Barrier: Influence of Cell and Culture-Related Factors on Caco-2 Cell Functional Characteristics. Cell Biol Toxicol 21, 1-26. doi:10.1007/s10565-005-0085-6

Sanae, F., Miyamoto, K.-i., Sawanishi, H., Kizu, H., Tomimori, Y., Sun, J.-n., et al. (1996). Hypoglycaemic Effects ofShokatsu-Cha(Xiao-Ke-Ca) in Streptozotocin-Induced Diabetes Mellitus. Phytother. Res. 10, 127-130. doi:10.1002/(sici) 1099-1573(199603)10:2<127:aid-ptr784>3.0.co;2-q

Schreck, K., and Melzig, M. F. (2018). Intestinal Saturated Long-Chain Fatty Acid, Glucose and Fructose Transporters and Their Inhibition by Natural Plant Extracts in Caco-2 Cells. Molecules (Basel, Switzerland) 23, 2544. doi:10.3390/ molecules 23102544

Schreck, K., and Melzig, M. F. (2019). The Expression of Selected Intestinal Glucose, Fructose and Long-Chain Fatty Acid Transporters Investigated in Caco-2 Cells. Planta Med. 85, 491.

Schulze, C., Bangert, A., Kottra, G., Geillinger, K. E., Schwanck, B., Vollert, H., et al. (2014). Inhibition of the Intestinal Sodium-Coupled Glucose Transporter 1 (Sglt1) by Extracts and Polyphenols from Apple Reduces Postprandial Blood Glucose Levels in Mice and Humans. Mol. Nutr. Food Res. 58, 1795-1808. doi: $10.1002 / \mathrm{mnfr} .201400016$

Sears, B., and Perry, M. (2015). The Role of Fatty Acids in Insulin Resistance. Lipids Health Dis. 14, 121. doi:10.1186/s12944-015-0123-1

Shah, M. A., Sarker, D. M. M. R., and Inamdar, M. (2016). Antidiabetic Potential of brassica Oleracea Var. Italica in Type 2 Diabetic sprague Dawley (Sd) Rats. Int. J. Pharmacognosy Phytochem. Res. 8, 462-469.

Shakeri, A., Sahebkar, A., and JavadiMelissa officinalis, B. 1. (2016). Melissa Officinalis L. - A Review of its Traditional Uses, Phytochemistry and Pharmacology. J. Ethnopharmacology 188, 204-228. doi:10.1016/ j.jep.2016.05.010

Sidorova, Y., Shipelin, V., Mazo, V., Zorin, S., Petrov, N., and Kochetkova, A. (2017). Hypoglycemic and Hypolipidemic Effect of Vaccinium Myrtillus L. Leaf and Phaseolus Vulgaris L. Seed Coat Extracts in Diabetic Rats. Nutrition 41, 107-112. doi:10.1016/j.nut.2017.04.010

Smirin, P., Taler, D., Abitbol, G., Brutman-Barazani, T., Kerem, Z., Sampson, S. R., et al. (2010). Sarcopoterium Spinosum Extract as an Antidiabetic Agent: In Vitro and In Vivo Study. J. Ethnopharmacology 129, 10-17. doi:10.1016/ j.jep.2010.02.021

Smith, S. C. (2007). Multiple Risk Factors for Cardiovascular Disease and Diabetes Mellitus. Am. J. Med. 120, S3-S11. doi:10.1016/j.amjmed.2007.01.002

Stöger, E. A. (2009). Arzneibuch der chinesischen medizin, monographien des arzneibuchs der volksrepublik china 2000 und 2005. Germany: Deutscher Apotheker Verlag Stuttgart.

Sugiyama, H., Akazome, Y., Shoji, T., Yamaguchi, A., Yasue, M., Kanda, T., et al. (2007). Oligomeric Procyanidins in Apple Polyphenol Are Main Active Components for Inhibition of Pancreatic Lipase and Triglyceride Absorption. J. Agric. Food Chem. 55, 4604-4609. doi:10.1021/jf070569k

Swanston-Flatt, S. K., Flatt, P. R., Day, C., and Bailey, C. J. (1991). Traditional Dietary Adjuncts for the Treatment of Diabetes Mellitus. Proc. Nutr. Soc. 50, 641-651. doi:10.1079/pns19910077

Tahraoui, A., El-Hilaly, J., Israili, Z. H., and Lyoussi, B. (2007). Ethnopharmacological Survey of Plants Used in the Traditional Treatment of Hypertension and Diabetes in South-Eastern morocco (Errachidia Province). J. Ethnopharmacology 110, 105-117. doi:10.1016/j.jep.2006.09.011 
Vuksan, V., Sung, M.-K., Sievenpiper, J. L., Stavro, P. M., Jenkins, A. L., Di Buono, M., et al. (2008). Korean Red Ginseng (Panax Ginseng) Improves Glucose and Insulin Regulation in Well-Controlled, Type 2 Diabetes: Results of a Randomized, Double-Blind, Placebo-Controlled Study of Efficacy and Safety. Nutr. Metab. Cardiovasc. Dis. 18, 46-56. doi:10.1016/j.numecd.2006.04.003

Wang, X., Liu, Q., Zhu, H., Wang, H., Kang, J., Shen, Z., et al. (2017). Flavanols from the Camellia Sinensis Var. Assamica and Their Hypoglycemic and Hypolipidemic Activities. Acta Pharmaceutica Sinica B 7, 342-346. doi:10.1016/j.apsb.2016.12.007

WHO (2019). Diabetes. Available at: https://www.who.int/en/news-room/factsheets/detail/diabetes (Accessed April, , 20).

WHO. Global Report on Diabetes; 2016.

Yellanur Konda, P., Egi, J. Y., Dasari, S., Katepogu, R., Jaiswal, K. K., and Nagarajan, P. (2020). Ameliorative Effects of Mentha Aquatica on Diabetic and Nephroprotective Potential Activities in Stz-Induced Renal Injury. Comp. Clin. Pathol. 29, 189-199. doi:10.1007/s00580-019-03042-6

Zhang, Y., Zhang, H., Wang, F., Yang, D., Ding, K., and Fan, J. (2015). The Ethanol Extract of Eucommia Ulmoides Oliv. Leaves Inhibits Disaccharidase and Glucose Transport in Caco-2 Cells. J. Ethnopharmacology 163, 99-105. doi:10.1016/ j.jep.2015.01.015
Zheng, Y., Scow, J. S., Duenes, J. A., and Sarr, M. G. (2012). Mechanisms of Glucose Uptake in Intestinal Cell Lines: Role of Glut2. Surgery 151, 13-25. doi:10.1016/ j.surg.2011.07.010

Conflict of Interest: The authors declare that the research was conducted in the absence of any commercial or financial relationships that could be construed as a potential conflict of interest.

Publisher's Note: All claims expressed in this article are solely those of the authors and do not necessarily represent those of their affiliated organizations, or those of the publisher, the editors and the reviewers. Any product that may be evaluated in this article, or claim that may be made by its manufacturer, is not guaranteed or endorsed by the publisher.

Copyright (c) 2021 Schreck and Melzig. This is an open-access article distributed under the terms of the Creative Commons Attribution License (CC BY). The use, distribution or reproduction in other forums is permitted, provided the original author(s) and the copyright owner(s) are credited and that the original publication in this journal is cited, in accordance with accepted academic practice. No use, distribution or reproduction is permitted which does not comply with these terms. 